\title{
The Role of Educational Sectors in Fighting Covid 19
}

\author{
Kaleab Tesfaye Tegegne ${ }^{1 *}$, Abiyu Ayalew Assefa ${ }^{1}$, Seblewongel Megersa ${ }^{1}$, Eleni Tesfaye Tegegne ${ }^{2}$ \\ and Mekibib Kassa Tessema ${ }^{3}$ \\ ${ }^{1}$ Department of Public Health, Hawassa College of Health Sciences, Ethiopia \\ ${ }^{2}$ School of Nursing, College of Medicine and Health Sciences, University of Gondar, Ethiopia \\ ${ }^{3}$ Leishmania Research and Treatment Center, University of Gondar, Ethiopia \\ *Corresponding author: Kaleab Tesfaye Tegegne, Department of Public Health, Hawassa College of Health Sciences, Hawassa, \\ Ethiopia
}

\section{ARTICLE INFO ABSTRACT}

Received: 蔧 March 30, 2021

Citation: Kaleab Tesfaye T, Abiyu Ayalew A, Seblewongel M, Eleni Tesfaye T, Mekibib Kassa T. The Role of Educational Sectors in Fighting Covid 19. Biomed J Sci \& Tech Res

Published: 幽 April 06, 2021 35(1)-2021. BJSTR. MS.ID.005634.

\section{Opinion}

In Africa, large number of communities has misconception that disease may be transmitted by utilizing health service due to a lack of trust in health service delivery. According to a health behavior model, knowledge and practice are contributing factors for increasing health care seeking among patients with low levels of trust [1]

The Ethiopian government has done many activities in disseminating health messages on radio and television, at national and regional level and there are strong initiatives and recognition of the public health importance of COVID-19. However, there is a need to increase community awareness and practices to slow spread of virus [2,3]. Effective mitigation and reduction of death and illness due to COVID-19 require behavioral change, which is influenced by people's knowledge and perceptions [4]. Recently the community knowledge and practice is not increased.

The education system is a large sector that makes it useful conduit into the community, especially through the parent body. The community of parents of learners at a school is not restricted to the demographic makeup of the community where the school property is physically located. More broadly than this, schools are the primary sector of government with a physical presence and relationship through parenthood with a significant proportion of adults in the population. Schools provide a substantial institutional base from which information and knowledge can be transferred to learners and their parents about health problems to individuals and the community at large [5]. Lack of information and advice from government can expose communities to panic [6]. The space opens up for 'infodemics' - 'the rapid spread of information of all kinds, including rumours, gossip and unreliable information [6].

Available communication channels and media need to be used to advice people how to respond, protect themselves and reduce the spread of the disease. This 'communication is critical to minimize the social, political and subsequently economic impact of an epidemic' [6]. According to Key outbreak response framework elements of WHO a role for schools is communicating risk that is relaying information, listening to and engaging communities, and managing rumors and misinformation. We recommend the educational sectors to focus on providing awareness and education for the community and students regarding the implementation of COVID 19 practices.

\section{References}

1. Lee H, Moon SJ, Ndombi GO, Kim K, Berhe H, et al. (2020) COVID-19 perception, knowledge, and preventive practice: Comparison between South Korea, Ethiopia, and Democratic Republic of Congo. African Journal of Reproductive Health 24(2): 66-77.

2. Kebede Y, Yitayih Y, Birhanu Z, Mekonen S, Ambelu A (2020) Knowledge, perceptions and preventive practices towards COVID-19 early in the outbreak among Jimma university medical center visitors, Southwest Ethiopia. PloS one 15(5): e0233744.

3. (2020) UNICEF, Creating awareness about covid-19. 
4. Akalu Y, Ayelign B, Molla MD (1949) Knowledge, attitude and practice towards COVID-19 among chronic disease patients at Addis Zemen Hospital, Northwest Ethiopia. Infection and drug resistance.

5. Prothero A (2020) Teachers' union gives guidance for schools on coronavirus. Education Week, 11 February 2020.

ISSN: 2574-1241

DOI: $10.26717 / B J S T R .2021 .35 .005634$

Kaleab Tesfaye Tegegne. Biomed J Sci \& Tech Res

(C) This work is licensed under Creative

Submission Link: https://biomedres.us/submit-manuscript.php
6. WHO (2018) Managing epidemics: Key Facts about major deadly diseases Geneva: World Health Organisation?

$\begin{array}{ll}\text { BIOMEDICAL } & \text { Assets of Publishing with us } \\ \text { RESEARCHES } & \text { - Global archiving of articles } \\ \text { - Immediate, unrestricted online access }\end{array}$

